\title{
Guidance for nuclear medicine staff on radiopharmaceuticals drug interaction
}

\author{
Ralph Santos-Oliveira* \\ Division of Radiopharmacy, Nuclear Engineering Institute, Brazil.
}

\begin{abstract}
Numerous drug interactions related to radiopharmaceuticals take place every day in hospitals many of which are not reported or detected. Information concerning this kind of reaction is not abundant, and nuclear medicine staff are usually overwhelmed by this information. To better understand this type of reaction, and to help nuclear medicine staff deal with it, a review of the literature was conducted. The results show that almost all of radiopharmaceuticals marketed around the world present drug interactions with a large variety of compounds. This suggests that a logical framework to make decisions based on reviews incorporating adverse reactions must be created. The review also showed that researchers undertaking a review of literature, or even a systematic review that incorporates drug interactions, must understand the rationale for the suggested methods and be able to implement them in their review. Additionally, a global effort should be made to report as many cases of drug interaction with radiopharmaceuticals as possible. With this, a complete picture of drug interactions with radiopharmaceuticals can be drawn.
\end{abstract}

Uniterms: Nuclear medicine. Radiology. Radiopharmaceuticals/drug interaction. Molecular imaging.

Diversos casos de interações medicamentosas com radiofármacos ocorrem diariamente na rotina hospitalar, contudo muitos deles não são notificados ou mesmo percebidos. Informações a respeito desse tipo de reação não é abundante e os profissionais da medicina nuclear muitas vezes estão assoberbados por essas informações. De modo a entender esse tipo de reação e auxiliar a medicina nuclear a lidar com essa situação uma revisão da literatura foi realizada. Os resultados mostraram que a totalidade dos radiofármacos comercializados no mundo apresentam interação medicamentosa com uma enorme variedade de outros medicamentos. Dessa forma sugere-se que revisões sobre radiofármacos inclua um capítulo sobre efeitos adversos. Além disso, um esforço mundial para notificar efeitos adversos deve ser realizado, pois somente dessa forma se terá um quadro real da situação referente interações medicamentosas com radiofármacos.

Unitermos: Medicina nuclear. Radiologia. Radiofármacos/interações medicamentosas. Imagem molecular.

\section{INTRODUCTION}

According to Mather (2001), radiopharmacy is scientifically recognized as an essential sub-specialty of nuclear medicine. Radiopharmaceuticals are used for two purposes; most importantly, is their use as diagnostic tools in clinical medicine. Radiopharmaceuticals also serve a purpose in research, both clinical and nonclinical, where they are used as tracers to observe or quantify biochemi-

\footnotetext{
*Correspondence: R. Santos-Oliveira. Instituto de Engenharia Nuclear, Divisão de Radiofarmácia, Rua Hélio de Almeida 75, Ilha do Fundão, 21941-906 - Rio de Janeiro - RJ, Brasil. Email: roliveira@ien.gov.br
}

cal or physiological processes (Tewson and Krohn 1998, Santos-Oliveira et al 2008).

Radiopharmaceuticals have been in use for many years for diagnosis and therapy of a wide variety of diseases (Sampson, 2003). In the early days of radiopharmacy, radiopharmaceuticals were generally prepared "in-house," and were not regarded as true medicines. In fact, they were, more often than not, prepared on the open bench where proper quality testing was not officially recognized.

There is a considerable body of evidence that biodistribution and pharmacokinetics of radiopharmaceuticals may be altered by a variety of drugs, disease conditions, and in some cases, surgical procedures (Hesslewood, 
Leung 1994). Drs. Sampson and Hesslewood (1989), state that these unknown and unrecognized interactions of radiopharmaceuticals with other compounds can lead to a state of total disorder.

Adverse drug reactions are a major cause of morbidity and mortality. In the United States, an estimated 701,547 people are seen every year at emergency departments due to adverse drug effects (Budnitz et al. 2006). Adverse event reporting databases provide no valuable information on incidence, as some events may not be recognized, and in many countries reporting is not mandatory. Therefore, the total incidence of drug-radiopharmaceutical interactions is unknown (Santos-Oliveira et al, 2008; Baranowska-Kortlylewicz, 2007).

It is important to clarify the difference between drug interaction and adverse reaction. Ryan et al. (1996) defined adverse reaction to radiopharmaceuticals as any response to a drug which is noxious and unintended, occurring at doses used in man for prophylaxis, diagnosis, therapy of disease, or for modification of physiological function.

Drug interaction is defined by the Food and Drug Administration (FDA, 2009) as drug-drug interactions that can lead to changed systemic exposure, resulting in variations in drug response of the co-administered drugs. Therefore, it is important to evaluate potential drug interactions prior to market approval as well as during the postmarketing period, especially with regard to radiopharmaceuticals.

\section{MATERIAL AND METHODS}

The location and the selection of studies is one of the most important steps in a review of literature, and it is necessary to develop a literature search strategy based on key elements. The review question determines the nature of the search strategy. In this case our question was simple:

\section{"Do radiopharmaceuticals present drug interactions?"}

To address this question a review of the literature was conducted for drug interactions with radiopharmaceuticals. We searched computerized databases on radiopharmaceuticals including MEDLINE, EMBASE, the International Pharmaceutical Abstracts and Science Citation Index (published from 1920 to April 2007) using "radiopharmaceuticals / drug interactions," "radiopharmaceuticals / interactions," and several other search terms. This was supplemented with manual searches of major radiopharmacy textbooks. This review of the literature uses a selection of the material collected, and includes controlled trials, cohort studies, case-control studies and case series, in English, French, Deutsch and Portuguese languages. The difficulties in finding studies related to radiopharmaceutical drug interactions forced the acceptance of studies of lower quality. Each of the papers were retrieved and reviewed.

\section{RESULTS AND DISCUSSION}

The search strategy identified forty potentially relevant papers. Two reviews described more than ten related cases. Other authors published aspects of a single study in a number of related papers. Each of the publications included in this study was located through our search, and all met the inclusion criteria.

The results are shown in Table I, which summarizes all of the principal studies related to radiopharmaceuticals and adverse reaction. In addition, this table can be used as a guide for all nuclear medicine staff as it is portable and easy to follow.

TABLE I - Summary of the compounds that might interfere with radiopharmaceuticals

\begin{tabular}{llll}
\hline Reference & Compound & Radiopharmaceuticals & Conclusion \\
\hline Fisher et al.(1977) & $\begin{array}{l}\text { Iodine-based } \\
\text { Antiseptics }\end{array}$ & Technetium-99 & Positive: reduce the uptake \\
\hline Sampson \& Hesselwood (1989)Chlorhexidine gluconate & Technetium-99 & Positive: reduce the uptake \\
\hline $\begin{array}{lll}\text { Slater } \text { et al. }(1983) \\
\text { components }\end{array}$ & All radiopharmaceuticals & $\begin{array}{l}\text { Positive: reduce the } \\
\text { radiopharmaceuticals } \\
\text { concentration in the sample }\end{array}$ \\
\hline Millar et al. (1983) & $\begin{array}{l}\text { Syringe and catheter } \\
\text { components }\end{array}$ & All radiopharmaceuticals & $\begin{array}{l}\text { Positive: reduce the } \\
\text { radiopharmaceutical } \\
\text { concentration in the sample }\end{array}$ \\
\hline Hladik et al. $(1987)$ & Spironolactone & Iodomethylnorcholesterol-131 & Positive: increase the uptake \\
\hline Fischer et al. (1982) & Spironolactone & Iodomethylnorcholesterol-131 & Positive: increase the uptake \\
\hline Khafagi et al. $(1991)$ & Spironolactone & Iodomethylnorcholesterol-131 & Positive: increase the uptake \\
\hline Gross, et al. $(1981)$ & Spironolactone & Iodomethylnorcholesterol-131 & Positive: decrease the uptake \\
\hline
\end{tabular}


TABLE I - Summary of the compounds that might interfere with radiopharmaceuticals (continuation)

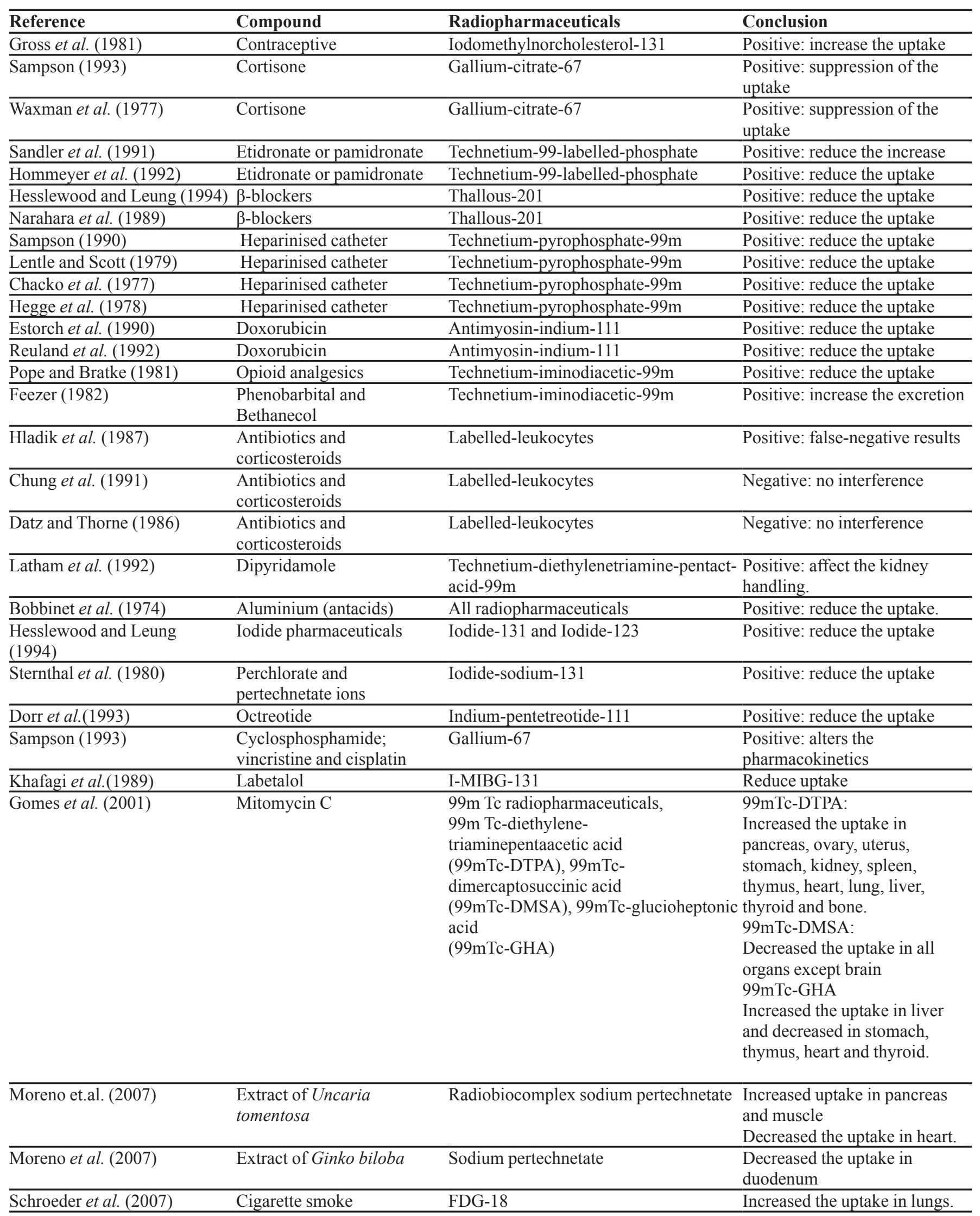




\section{CONCLUSION}

The results showed that numerous drugs may interfere with radiopharmaceutical metabolism or biodistribution, and consequently, efforts must be made to minimize this type of event.

Our findings (Table I) can be particularly useful for the daily routine of nuclear medicine staff in hospitals where quick guides are always welcome.

In light of our results, drug interactions with radiopharmaceuticals should be better documented and reported. Efforts to increase adverse event reporting, and ideally consolidate reports worldwide, can provide a critically needed resource for prevention of drug-radiopharmaceuticals interactions.

\section{REFERENCES}

BARANOWSKA-KORTLYLEWICZ, J. B. Radioactive drugs in drug development research: quality assurance issues. Mini-Rev. Med. Chem., v.7, n.3, p.231-244, 2007.

BOBINET, E. B.; SEVERIN, M.; ZURBRIGGEN, M. T. Lung uptake of tc-99m sulphur colloid in patients exhibiting presence of aluminium in plasma. J. Nucl. Med., v.15, n.12, p.1120-1222, 1974.

CHACKO. A. K.; GORDON, D. H.; BENNET, J. M.; O'MARA, R. E.; WILSON, G. A. Myocardial imaging with tc-99m pyrophosphate in patients on adriamycin treatment for neoplasia. J. Nucl. Med., v.18, n.7, p.680-683, 1977.

CHUNG, C. J.; HICKLIN, O. A.; PAYAN, J. M.; GORDON, L. Indium-111-labeled leukocyte scan in detection of synthetic vascular graft infection: the effect of antibiotic treament. $J$. Nucl. Med., v.32, n.1, p.13-15, 1991.

DATZ, F. L.; THORNE, D. A. Effect of antobiotic therapy on the sensitivity of indium-111-labelled leukocyte scans. $J$. Nucl. Med., v.27, n.12, p.1849-1853, 1986.

DORR, U.; RATH, U.; SAUTER-BIHL, M. -L.; GUZMAN, G.; BACH, D.; ADRIAN, H. J., BIHL, H. Improved visualization of carcinoid liver metastases by indium-111 pentetreotide scintigraphy following treatment with cold somatostatin analogue. Eur. J. Nucl. Med., v.20, n.5, p.431433, 1993.

EARLY, P. J. Use of diagnostic radionuclides in medicine. Health Phys., v.69, n.5, p.649-661, 1995.
ESTORCH, M.; CARRIO, I.; BERNA, L.; MARTINEZDUNCKER, C.; ALONSO, C.; GÉRMAN, J. P.; OJED, A. B. Indium-111 antimyosin scintigraphy after doxorubicin theraphy in patientes with advanced breast cancer. J. Nucl. Med., v.31, n.12, p.1965-1969, 1990.

FEEZER E. A. Hepatobiliary imaging: general considerations. The view box, july issue, Dep. Nucl. Med, Wesley Medical Centre, 400pp, 1982 apud SANTOS-OLIVEIRA, R. Radiopharmaceutical drug interactions. Rev. Salud Pública, v.10, n.3, p.477-487, 2008.

FISCHER, M.; VETTER, W.; WINTER, B. Adrenal scintigraphy in primary aldosteronism: Spironolactona as a cause of incorrect classification between adenona and hyperplasia. Eur. J. Nucl. Med., v.7, n.2, p.222-224, 1972.

FISCHER, M.; WINTERBERG, B.; MULLER-RENSING, R. Radioisotopic therapy of pheochromocytoma. Nuc. Compact., v.14, n.114, p.172-176, 1982.

FOOD AND DRUG ADMINISTRATION. FDA. Center for Drug Evaluation and Research. Drug Development and Drug Interactions. Avaiable at: http:/www.fda.gov/Cder/ drug/drugInteractions/default.htm. Accessed on: 01 jan. 2009.

GOMES, M. L.; MATTOS, D. M. M.; SOUZA-FREITAS, R.; BEZERRAL, R. J.; BERNARDO-FILHO, M. Study of the toxicological effect of mitomycin $\mathrm{c}$ in mice: alteration on the biodistribution of radiopharmaceuticals used for renal evaluations. Hum. Exp. Toxicol., v.20, n.4, p.193-197, 2001.

GROSS, M. D.; VALK, T. W.; SAWANSON, D. P.; THRALL, J. H.; GREKIN, R. J.; BEIREWALTES, W. H. The role of pharmacologic manipulation in adrenal cortical scintigraphy. Semin. Nucl. Med., v.11, n2, p.128-148, 1981.

HEGGE, F. N.; HAMILTON, G. W.; LARSON, S. M. Cardiac chamber imaging: a comparison of red blood cells labeled with tc-99m in vitro and in vivo. J. Nucl. Med., v.19, n.2, p.129-134, 1978.

HESSLEWOOD, S.; KEELING, D. H. 1997. Frequency of adverse reactions to radiopharmaceuticals in Europe. Eur. J. Nucl. Med., v.24, n.4, p.1179-1182, 1997.

HLADIK, W. B.; PONTO, J. A.; LENTLE, B. C.; LAVEN, D. L. Iatrogenic alterations in the biodistribution of radiotracers as a result of drug therapy: reported instances. In: HLADIK W. B.; SAHA, G. B.; STUDY, K. T. (Eds), Essentials of 
nuclear medicine sciences. Sydney: Williams and Wilkins, 1987. p.189-219.

HOMMEYER, S. H.; VARNEY, D. M.; EARY, J. F. Skeletal non-visualization in a bone scan secondary to intravenous etidronate therapy. J. Nucl. Med., v. 3, n.5, p.748750, 1992.

JONES, J. K. Adverse drug reactions in the community health setting: approaches to recognizing, counseling, and reporting. Fam. Comm. Health., v.5, n.2, p.58-67, 1982.

KEELING, D. H. Adverse reactions and untoward events associated with the use of radiopharmaceuticals. In: SAMPSON, C. B. (Ed.). Textbook of radiopharmacy theory and practice. Yverdon: Gordon and Breanch Science Publishers, 1994. p.285-295.

KHAFAGI, F.; SHAPIRO, B.; LORRAINE, M.; MALLETTE, S.; SISSON, J. C. Labetolol reduces iodine-131-mibg uptake by pheochromacytom and normal tissues. J. Nucl. Med., v.30, n.4, p. 481-489, 1989.

KHAFAGI, F. A.; SHAPIRO, B.; GROSS, M. D. The adrenal gland apud MAISEY, M. N.; BRITTON, K. E.; GILDAY, D. L. Clinical nuclear medicine. London: Chapman and Hall, 1991. p. 271-291.

LATHAM, T. B.; PRATO, F. S.; WISENBERG, G.; REESE, L. Effects of dipyridamole infusion on human renal function observed using technetium-99m-dtpa. J. Nucl. Med., v.33, n.3, p.355-358, 1992.

LENTLE, B. C.; SCOTT, J. R. Iatrogenic alterations in radionuclide biodistribution. Semin. Nucl. Med., v.9, n.2, p.131-134, 1979.

MATHER, S. J. Innovation in radiopharmacy: progress and constraints? Eur. J. Nucl. Med., v.28, n.4, p.405-407, 2001.

MEYER, G. J.; WATERS, S. L.; COENEN, H. H.; LUXEN, A.; MAZIERE, B.; LANGSTRÖM, B. PET radiopharmaceuticals in Europe: current use and data relevant for the formulation of summaries of product characteristics (SPCs). Eur. J. Nucl. Med., v. 22, n.12, p.1420-1432, 1995.

MILLAR, A. M.; WATHEM, C. J.; MUIR, A. L. Failure in labelling of red cells with tc-99: interaction between intravenous cannulae and stannous pyrophosphate. Eur. J. Nucl. Med., v.8, n.11, p.502-504, 1983.
MORENO, S. R. F.; SILVA, A. L.; DIRÉ, G.; HONEYCUR, H.; CARVALHO, J. J.; NASCIMENTO, A. L.; PEREIRA, M.; ROCHA, E. K.; OLIVEIRA-TIMÓTEO, M.; ARNOBIO, A.; OLEJ, B.; BERNARDO-FILHO, M.; CALDAS, L. Q. Effect of oral ingestion of an extract of the herb Uncaria tomentosa on the biodistribution of sodium pertechnetate in rats. Braz. J. Med. Biol. Res., v.40, n.1, p.77-80, 2007.

MORENO, S. R. F.; CARVALHO, J. J.; NASCIMENTO, A. L.; PEREIRA, M.; ROCHA, E. K.; OLEJ, B.; CALDAS, L. Q. A.; BERNARDO-FILHO, M. Experimental model to assess possible medicinal herb interaction with a radio-complex: Qualitative and quantitative analysis of kidney, liver and duodenum isolated from treated rats. Food Chem. Toxicol., v.45, v.5, p.19-23, 2007

NARAHARA, K. A.; THOMPSON, C. J.; HAZEN, J. F.; BRIZENDINE, M.; MENA, I. The effect of beta-blockade on single photon emission computed tomographic (SPECT) thallium-201 images in patients with coronary disease. Am. Heart. J., v.117, n. 5, p.1030-1035, 1989.

NUMEROF, P. Radiopharmaceutical development in nuclear medicine. Lahey Clinic Found. Bull., v.16, n.4, p.321-326, 1967.

POPE, R.; BRATKE, J. Two Tc-99mhda cases with delayded emptying into the duodenum. Monthly scan: College of Pharmacy New Mexico, Monthly Newsletter, May/June, sp, 1981.

REULAND, P.; RUCK, P.; FEINE, U. Correlation of chemotherapy-induced kidney disorder and antimyosin antibody uptake in kidneys. J. Nucl. Med., v.33, n.2, p.309311, 1992.

SAMPSON, C. B. Drugs and chemicals which affect the purity, biodistribution and pharmacokinetics of radiopharmaceuticals. J. Biopharm. Sci., v.1, n.2, p.381400, 1990.

SAMPSON, C. B. Adverse reactions and drug interaction with radiopharmaceuticals. Drug Saf., v.8, n.4, p.280-294, 1993.

SAMPSON, C. B.; HESSLEWOOD, S. R. Altered biodistribution of radiopharmaceuticals as a result of pharmacological or chemical interaction. J. Biopharm., v.5, n.1, p. 131-151, 1989. 
SANDLER, E. D.; PARISI, M. T.; HATTNER, R. S. Duration of etidronate effect demonstrated by serial bone scintigraphy. J. Nucl. Med. v.32, n.9, p.1782-1784, 1991.

SANTOS-OLIVEIRA, R.; CARNEIRO-LEÃO, A. M. A.; SMITH, S.W. Radiopharmaceuticals drug interactions: a critical review. Ann. Acad. Nac. Cienc., v.80, n.4, p.665$675,2008$.

SCHROEDER, T.; VIDAL -MELO, M.; MUSCH, G.; HARRIS, R. S.; WINKLER, T.; VENEGAS, J. G. Pet imaging of regional 18-f-fdg uptake and lung function after cigarette smoke inhalation. J. Nucl. Med., v.48, n.3, p 413-419, 2007.

SLATER, D. M.; ANDERSON, M.; GARVIE, N. W. Syringe extractables, effects on radiopharmaceuticals. Lancet, v.17, n.2 (8364), p.1431-1432, 1983.
SIILBERSTEIN, E. B. Positron-emitting radiopharmaceuticals: how safe are they? Cancer Bioth. Radiohar., v.16, n.1, p.13-15, 2001.

STERNTHAL, E.; LIPWORTH, L.; STANLEY, B.; ABREAU, C.; FANG, S. L.; BRAVEMAN, L. E. Suppression of thyroid radioiodine uptake by various doses of stable iodine. N. Engl. J. Med., v. 303, n.19, p.1083-1088, 1980.

TEWSON, T. J.; KRHON, K. A. Pet radiopharmaceuticals: state-of-the-art and future prospects. Semin. Nucl. Med., v.28, n.3, p.221-234, 1998.

WAXMAN, A. S.; BELDON, J. R.; RICHLI, W. R.; TANASESCU, D. E.; SIEMSEN, J. K. Steroid-induced suppression of gallium uptake tumours of the central nervous system. J. Nucl. Med., v.19, n.5, p. 617, 1997.

Received for publication on $25^{\text {th }}$ September 2008 . Accepted for publication on $24^{\text {th }}$ March 2009. 